\title{
Geochemical evaluation of fluoride contamination of groundwater in the Thoothukudi District of Tamilnadu, India
}

\author{
C. Singaraja $\cdot$ S. Chidambaram $\cdot$ P. Anandhan $\cdot$ \\ M. V. Prasanna $\cdot$ C. Thivya $\cdot$ R. Thilagavathi $\cdot$ \\ J. Sarathidasan
}

Received: 8 August 2012/ Accepted: 10 February 2014/Published online: 20 March 2014

(C) The Author(s) 2014. This article is published with open access at Springerlink.com

\begin{abstract}
Fluoride is a chemical element that has been shown to cause significant effects on human health through drinking water. Different forms of fluoride exposure are of importance and have shown to affect the body's fluoride content and thus increasing the risks of fluoride-prone diseases. Fluoride has beneficial effects on teeth; however, low concentrations of fluoride intensify the risk of tooth decay. Fluoride can also be quite detrimental at higher concentrations at skeletal fluorosis. The Thoothukudi District is a hard rock and alluvial plain marked as one of the Fluoride-increase area in Tamilnadu due to occurrence of various rock types including fluoride-bearing minerals. The $\mathrm{F}^{-}$content of groundwater can thus originate from the dissolution of Fluoride-bearing minerals in the bed rock.
\end{abstract}

C. Singaraja $(\bowtie) \cdot$ S. Chidambaram · P. Anandhan ·

C. Thivya $\cdot$ R. Thilagavathi $\cdot$ J. Sarathidasan

Department of Earth Sciences, Annamalai University,

Annamalai Nagar 608002, India

e-mail: geolionking@gmail.com

S. Chidambaram

e-mail: chidambaram_s@rediffmail.com

P. Anandhan

e-mail: vijayanand_pa@yahoo.com

C. Thivya

e-mail: thivyac1988@gmail.com

R. Thilagavathi

e-mail: thilagavathir@ymail.com

J. Sarathidasan

e-mail: sarathidasan@gmail.com

M. V. Prasanna

Department of Applied Geology, School of Engineering and Science, Curtin University, CDT 250, 98009 Miri, Sarawak, Malaysia

e-mail: geoprasanna@gmail.com
Hundred representative groundwater samples from Thoothukudi District were collected during two different seasons. Samples were analysed for $\mathrm{F}^{-}$, other major cations and anions. The study area is chiefly composed of hornblende biotite gneiss, charnockite, alluvio marine, fluvial marine and granite with small patches of quartzite and sandstone. Higher concentration of fluoride is observed during pre-monsoon $\left(3.3 \mathrm{mg} \mathrm{l}^{-1}\right)$ compared to the postmonsoon $\left(2.4 \mathrm{mg} \mathrm{l}^{-1}\right)$ due to the dilution effect. Spatial distribution and factor score show that higher concentrations of $\mathrm{F}^{-}$are noted in the north and central part of the study area owing to lithology. Bicarbonate is well correlated with $\mathrm{F}^{-}$which explains that both ions were derived from the weathering. While $\mathrm{F}^{-}$has a very weak correlation with $\mathrm{pH}$ which may be due to the increase of alkalinity resulting from the increase of carbonate and bicarbonate ions.

Keywords Fluoride - Drinking water · Hard rock · Lithology $\cdot$ Weathering

\section{Introduction}

Water is a leading natural resource and essential for life on earth. About $80 \%$ of the diseases in the world are due to poor quality of drinking water (WHO 1984).In groundwater, the natural concentration of fluoride depends on the geological, chemical and physical characteristics of the aquifer, the porosity and acidity of the soil and rocks, the temperature and the action of other chemical elements (Tahaikt et al. 2008). Fluoride ion in drinking water is known for both beneficial and detrimental effects on health. The total number of people affected in the world is not well known. Per day fluoride intake is directly related with the 
daily water intake. Therefore, USPHS (1962) set a range of allowable concentrations for fluoride in drinking water according to the climatic conditions (especially temperature).

Fluoride is essential for the development of tooth enamel, dentin, and the bones. It is harmful when it exceeds the permissible limit of $1.5 \mathrm{mg} \mathrm{l}^{-1}$ (WHO 2008) in water. Low concentration of fluoride below $0.5 \mathrm{ppm}$ causes dental caries (Clark 1993; Jones et al. 1997; Acharya et al. 2008). Smaller quantities $\left(<1.0 \mathrm{mg} \mathrm{l}^{-1}\right)$ in drinking water are usually considered good to have a beneficial effect on the rate of occurrence of dental carries, particularly among children (WHO 1997; Hussain et al. 2004, 2010). While high concentrations above $1.5 \mathrm{mg} \mathrm{l}^{-1}$ may cause an endemic disease called dental fluorosis, intake of $\mathrm{F}^{-}$concentrations above $3.0 \mathrm{mg} \mathrm{l}^{-1}$ may cause skeletal fluorosis (Handa 1975; WHO 1984; Vollmer 1993; Ripa 1993).

In India, it was first detected in Nellore District of Andhra Pradesh (Shortt 1937). Presently 22 states have been identified as endemic for fluorosis in man (Siddiqui 1955; Jolly et al. 1973). India has the most extensive areas of high $\mathrm{F}^{-}$ground waters. In India about 62 million people are at risk of developing fluorosis from drinking high $\mathrm{F}^{-}$water (Susheela 1999; Andezhath et al. 1999). Dental fluorosis is endemic in 14 states and 150,000 villages in India (Pillai and Stanley 2002). The problems are most pronounced in the states of Andhra Pradesh, Bihar, Gujarat, Madhya Pradesh, Punjab, Rajasthan, Uttar Pradesh and Tamilnadu is one of them (Pillai and Stanley 2002). Fluorosis is a considerable health problem worldwide, which is afflicting millions of people in many areas of the world, for example East Africa (Nanyaro et al. 1984; Gaciri and Davies 1993; Gizaw 1996), Turkey (Oruc 2003), India (Hussain 2001; Rao and Devadas 2003; Gupta et al. 2005), southeastern Korea (Kim and Jeong 2005) and northern China (Wang and Reardon 2001). The main source of fluoride in the groundwater is fluoride-bearing rocks from which it get weathered and/or leached out contaminating the water. Fluorides occur in three forms, namely fluorspar or calcium fluoride $\left(\mathrm{CaF}_{2}\right)$, apatite or rock phosphate $\left[\mathrm{Ca}_{3} \mathrm{~F}\left(\mathrm{PO}_{4}\right)_{3}\right]$ and cryolite $\left(\mathrm{Na}_{3} \mathrm{AlF}_{6}\right)$ (Sunitha et al. 2012). Fluoride content in groundwater is mainly due to natural contamination, but the process of dissolution is still not well understood (Handa 1975; Saxena and Ahmed 2001).The study area is a hard rock terrain and the fluoride in drinking water is mainly reported in the hard rock terrains in India (Siddiqui 1968; Handa 1975; Ramesham and Rajagopalan 1985; Rao and Devadas 2003; Gupta et al. 2005; Jacks et al. 2005; Shaji et al. 2007; Srinivasamoorthy et al. 2008; Reddy et al. 2010; Ramachandran et al. 2010; Deepu and Shaji 2011; Chidambaram et al. 2012; Singaraja et al. 2013b). In general, potential sources of fluoride in groundwater include various minerals in rocks and soils, such as fluorite, apatite, amphiboles and micas (Handa 1975; Pickering 1985; Wenzel and Blum 1992; Bardsen et al. 1996; Rao and Devadas 2003). Although high $\mathrm{F}^{-}$ concentrations in groundwater were previously considered to be a problem mainly in hard rock areas, they have now been discovered in other environments as well (Chadha and Tamta 1999). Therefore, some researchers suggested that high fluoride concentrations in groundwater are likely a result of the dissolution of Biotite, which may contain significant fluorine at the $\mathrm{OH}^{-}$sites of their octahedral sheet (Nordstrom et al. 1989; Li et al. 2003).

Many workers (Karthikeyan and Shanmugasundarraj 2000; Srinivasamoorthy et al. 2008; Alagumuthu and Rajan 2010; Ramachandran et al. 2010; Chidambaram et al. 2012) have reported the level of fluoride concentration in different districts of Tamilnadu, and Thoothukudi is one of them. The high fluoride (4.34 $\mathrm{mg}^{-1}$ ) contamination in drinking water was reported in Ottapidaram block part of Thoothukudi District (Veeraputhiran and Alagumuthu 2010). The main objectives of this study are: (1) to demarcate the relevant factors affecting the natural fluoride contamination in the ground waters (2) to understand the spatial and saturation index of fluoride and (3) fluoride relationship between the other hydrogeochemical parameters.

\section{Materials and method}

\section{Study area}

The study area of the Thoothukudi District $\left(8^{\circ} 19^{\prime}\right.$ to $9^{\circ} 22^{\prime}$ $\mathrm{N}$ latitude and $77^{\circ} 40^{\prime}$ to $78^{\circ} 23^{\prime} \mathrm{E}$ longitude) is located in southeast coast of Tamilnadu (India). It is a hard rock terrain with a total area of 4,590.54 sq.km (Fig. 1). Geologically, three major units exist in this area, hornblende biotite gneiss (HBG), alluvio marine and fluvial marine (Fig. 1). The HBG is the dominant formation; however, alluvial marine and fluvial marine are found in the coastal region and are dominant in the eastern part of the study area. Four charnockite patches are noted in the study area, one in the central part of the study area and the other along the western margin. The structural control is well represented in the rock types of the study area which namely aregranite, quartzite and sandstone occurrences. Vaipar, Tambraparani and Karamanaiyar are the major rivers draining the district. All the rivers are ephemeral in nature and runoff is generated in heavy rainfall period only. The climate in this area is generally tropical with an annual rainfall that ranges between 570 and $740 \mathrm{~mm}$.

Major water-bearing formations are quaternary alluvium, tertiary sediments, teri sands, weathered fractured pink granites, charnockites and gneisses. Limited fresh water availability in sedimentary areas is present (Central 
Fig. 1 Sampling location and Geology map of the study area (after Singaraja et al. 2013a)

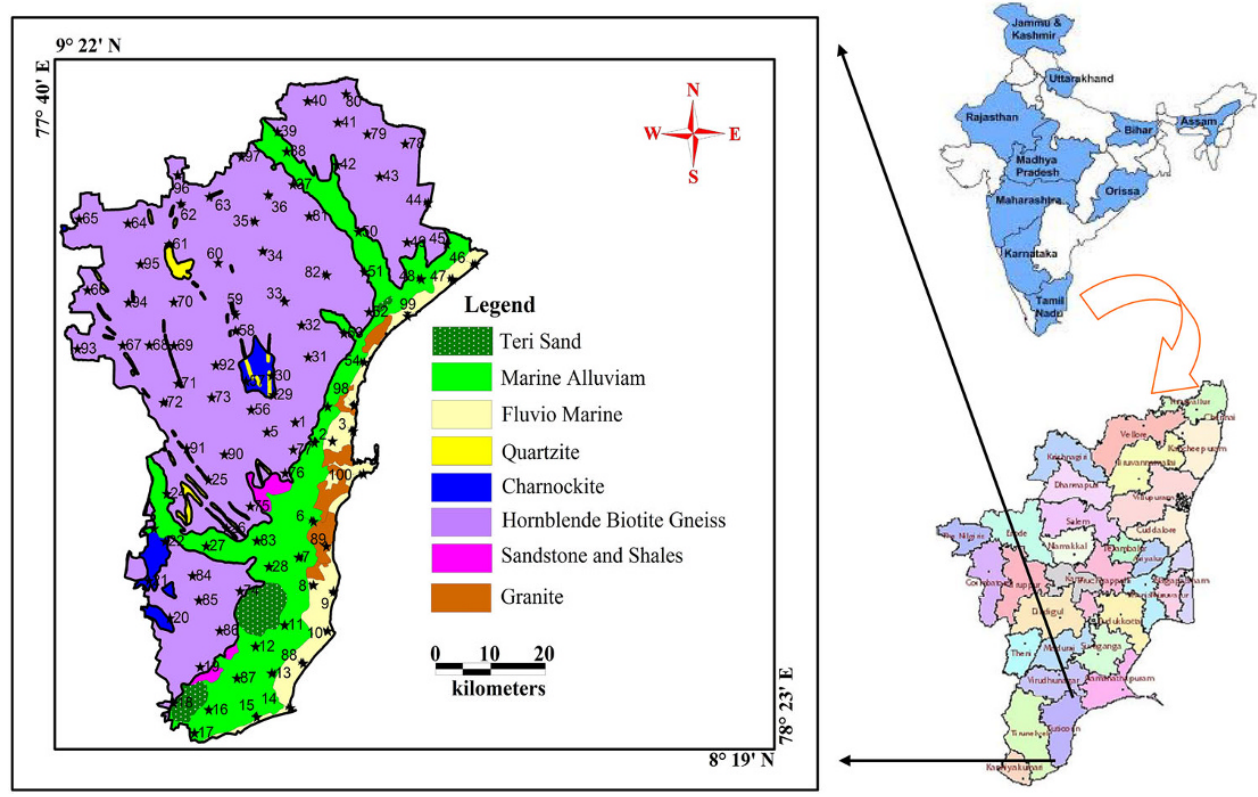

Results and discussion

Ground Water Board 2009). The types of industries found here include petrochemicals, thermal power plant, heavy water plant (HWP), chlor-alkali, $\mathrm{HCl}$, trichloro-ethylene, cotton and staple yarn, caustic soda, poly vinyl chlorine resin, fertilizers, soda ash, carbon dioxide gas in liquid form and aromatics. The public sector undertakings are the Thoothukudi Thermal Power Station unit, HWP and Port Trust. Though there are different studies in the land-use and land-cover pattern in the study area along with few reports on the metal pollution in groundwater to highlight their effects of the industrial (SIPCOT) effluents on the Thoothukudi city (SelvinPitchaikani et al. 2010; Singaraja et al. 2013c).

Sample collection and analysis

A total of 100 water samples were collected from entire districts during Pre-monsoon (PRM) (May) and Postmonsoon (POM) (February). Water samples were collected from hand pumps after purging for 5-10 min and $500 \mathrm{ml}$ of the sample was collected in the precleaned Teflon bottles without any air gap and sealed with a stopper. Immediately after collection, samples were stored at $4{ }^{\circ} \mathrm{C}$ in an ice chest and transported to laboratory for the chemical analysis. The $\mathrm{pH}$, electrical conductivity (EC) and fluoride $\left(\mathrm{F}^{-}\right)$were immediately analysed using the Orion Ion hand-held electrodes after collection. $\mathrm{HCO}_{3}{ }^{-}$by titrimetry; $\mathrm{Cl}^{-}$, $\mathrm{SO}_{4}{ }^{2-}, \mathrm{PO}_{4}{ }^{-}, \mathrm{NO}_{3}{ }^{-}, \mathrm{H}_{4} \mathrm{SiO}_{4}, \mathrm{Ca}^{2+}, \mathrm{Mg}^{2+}, \mathrm{Na}^{+}$and $\mathrm{K}^{+}$by the ion chromatograph (IC, Metrohm 861). Duplicate samples were analysed to check the analytical precision; it is $\pm 5 \%$ for all hydrogeochemical variables. The saturation indices (SI) of fluoride minerals were computed using the WATEQ4F (Hammarstrom et al. 2005).
Water chemistry

Fluorine is highly reactive and is found naturally as $\mathrm{CaF}_{2}$. It is an essential constituent in minerals like topaz, fluorite, fluorapatite, cryolite, phosphorite, theorapatite, etc. (Singh and Maheshwari 2001). The fluoride is found in the atmosphere, soil and water. It enters the soil through weathering of rocks, precipitation or waste runoff. The representations of the analysed parameters for the samples collected are shown in Fig. 2. This figure is a box plot with upper and lower quartiles of the data defining the top and the bottom of a rectangle box. The line inside the box represents the median value and the size of the box represents the spread of the central value (TaheriTizro and Voudouris 2008). The geochemical trend of groundwater in the study area (Fig. 2) demonstrates that Sodium is the dominant cation $\left(\mathrm{Na}^{+}>\mathrm{Ca}^{2+}>\mathrm{Mg}^{2+}>\mathrm{K}^{+}\right)$. In majority of the samples $\mathrm{Na}^{+}, \mathrm{Mg}^{2+}$ and $\mathrm{K}^{+}$are above the median in the plot, whereas in the majority of the samples, $\mathrm{Ca}^{2+}$ is below the median to minimum level and Chloride is the dominant anion $\left(\mathrm{Cl}^{-}>\mathrm{HCO}_{3}{ }^{-}>\mathrm{SO}_{4}{ }^{2-}>\mathrm{H}_{4} \mathrm{SiO}_{4}>-\right.$ $\left.\mathrm{NO}_{3}{ }^{-}>\mathrm{F}^{-}\right) . \mathrm{Cl}^{-}, \mathrm{NO}_{3}{ }^{-}$and $\mathrm{SO}_{4}{ }^{2-}$ in most of the samples fall above the median to maximum level, $\mathrm{HCO}_{3}{ }^{-}, \mathrm{F}^{-}$, $\mathrm{H}_{4} \mathrm{SiO}_{4}$ in majority of the samples lie between the median to maximum in anion during PRM. $\mathrm{Na}^{+}, \mathrm{Mg}^{2+}$ and $\mathrm{Ca}^{2+}$ show equal distribution of all the samples between minimum to maximum, but in most of the samples $\mathrm{K}^{+}$ falls above the median in cation $\left(\mathrm{Na}^{+}>\mathrm{Mg}^{2+}>\mathrm{Ca}^{2+}>\mathrm{K}^{+}\right)$. $\mathrm{Cl}^{-}, \mathrm{NO}_{3}{ }^{-}, \mathrm{F}^{-}$and $\mathrm{H}_{4} \mathrm{SiO}_{4}$ show that most of the samples fall above the median to maximum level; and in the majority $\mathrm{SO}_{4}{ }^{2-}$ lies between the median to minimum 

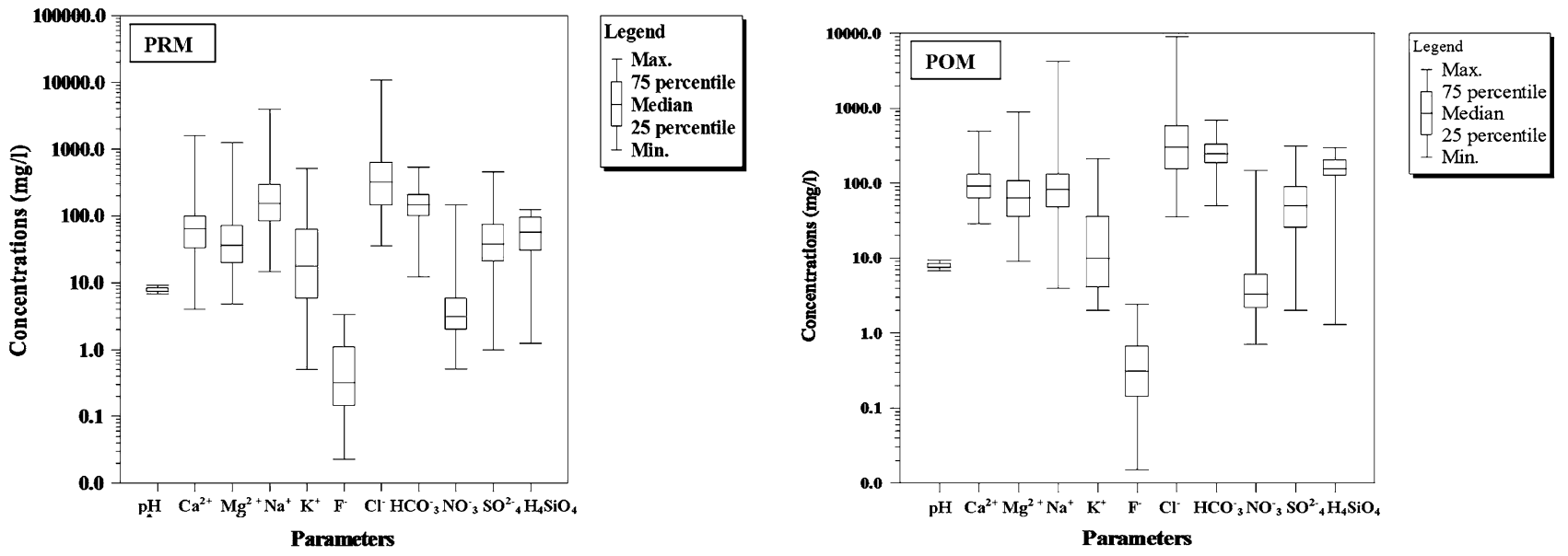

Fig. 2 Box plot for the maximum, minimum and average of the chemical constituents in groundwater during PRM and POM (all values in $\mathrm{mg} \mathrm{l}^{-1}$ except $\left.\mathrm{pH}\right)$

Table 1 Range of $\mathrm{F}^{-}$concentration $\mathrm{s}\left(\mathrm{mg} \mathrm{l}^{-1}\right)$ in groundwater of both seasons $(n=100)$

\begin{tabular}{llll}
\hline Seasons & $0-1$ & $1-1.5$ & $>1.5$ \\
PRM & 78 & 14 & 8 \\
POM & 85 & 9 & 6 \\
\hline
\end{tabular}

$\left(\mathrm{Cl}^{-}>\mathrm{HCO}_{3}{ }^{-}>\mathrm{SO}_{4}{ }^{2-}>\mathrm{H}_{4} \mathrm{SiO}_{4}>\mathrm{NO}_{3}{ }^{-}>\mathrm{F}^{-}\right)$during POM. In fluoride 14 and $9 \%$ of the samples fall in the range of 1-1.5 $\mathrm{mg} \mathrm{l}^{-1}$ during PRM and POM, respectively. Very high concentrations $\left(>1.5 \mathrm{mg} \mathrm{l}^{-1}\right)$ are also noted in PRM (8\%) compare to the POM (6\%) (Table 1), which may be due to that fact that dilution has played a significant role during the POM which resulted in the lesser $\mathrm{F}^{-}$in groundwater (Chidambaram et al. 2012). It is interesting point to note that highest concentration range observed during PRM is $3.3 \mathrm{mg}^{-1}$ but during POM it is $2.4 \mathrm{mg} \mathrm{l}^{-1}$. Hence, it is clearly evident that there is a decrease in concentration of $\mathrm{F}^{-}$ions during the POM indicating a similar dilution effect to that observed in Dindigul District, Tamilnadu (Ramachandran et al. 2010). This fact confirms the seasonal fluoride level fluctuation in water, its variation with season.

\section{Spatial distribution of fluoride}

The spatial distribution of fluoride in groundwater samples in the study area is represented as a thematic layer using Map info GIS software. The distribution of fluoride in the groundwater of the Thoothukudi District is shown in Fig. 3. Fluoride concentration ranges from below detection limit (BDL) to $3.3 \mathrm{mg} \mathrm{l}^{-1}$. Higher concentrations $\left(>1 \mathrm{mg} \mathrm{l}^{-1}\right)$ of $\mathrm{F}^{-}$are noted in the north and central part of the study area where the geology of the study area is complex comprising of the HBG, alluvial plain followed by charnockite. Fluoride concentrations ranging between 0.5 and $1 \mathrm{mg}^{-1}$ are noted in the central, the northern and north eastern part of the study area and the lowest concentration is noted in the southern, western and the eastern part of the study area during PRM. In POM, Fluoride concentration ranges from BDL to $2.4 \mathrm{mg} \mathrm{l}^{-1}$. The higher concentration is again noted in the same area (Fig. 3) as that of the PRM. The spatial distribution of $\mathrm{F}^{-}$in both the seasons reveals that highest fluoride concentrations are shown in the North and central part of the study area, indicating a lithological control over the spatial distribution of fluoride. Similar type of relationship of fluoride ions to different rock types of the Erode District was studied by Chidambaram et al. (2003). Srinivasamoorthy (2005) studied the spatial distribution of fluoride in groundwater of the Salem District of Tamilnadu, India, and he also proved that higher concentrations of fluorides are confined to lithological contacts.

In general, in hard rock terrain, water quality variations and changes are common, especially for fluoride in shallow, intermediate and deep aquifers. In alluvial plain groundwater, however, such variation and changes in fluoride levels are usually rare. Similar observations were noted in Ganges alluvial plain, fluoride contamination has been reported by Indian state and central groundwater departments in a few districts like Unnao, Kanpur, and Agra (Misra et al. 2006). The sources of geogenic (apatite, biotite, and clays) and anthropogenic(chemical fertilizers), with a combination of higher rate of evaporation and longer interaction of water with the aquifer materials under alkaline environment, are the key factors for the concentration of $\mathrm{F}^{-}$in the study area (SubbaRao 2009). High concentrations of fluoride in groundwater were noted in granite and granitoid gneiss (Kim et al. 2006). Low 

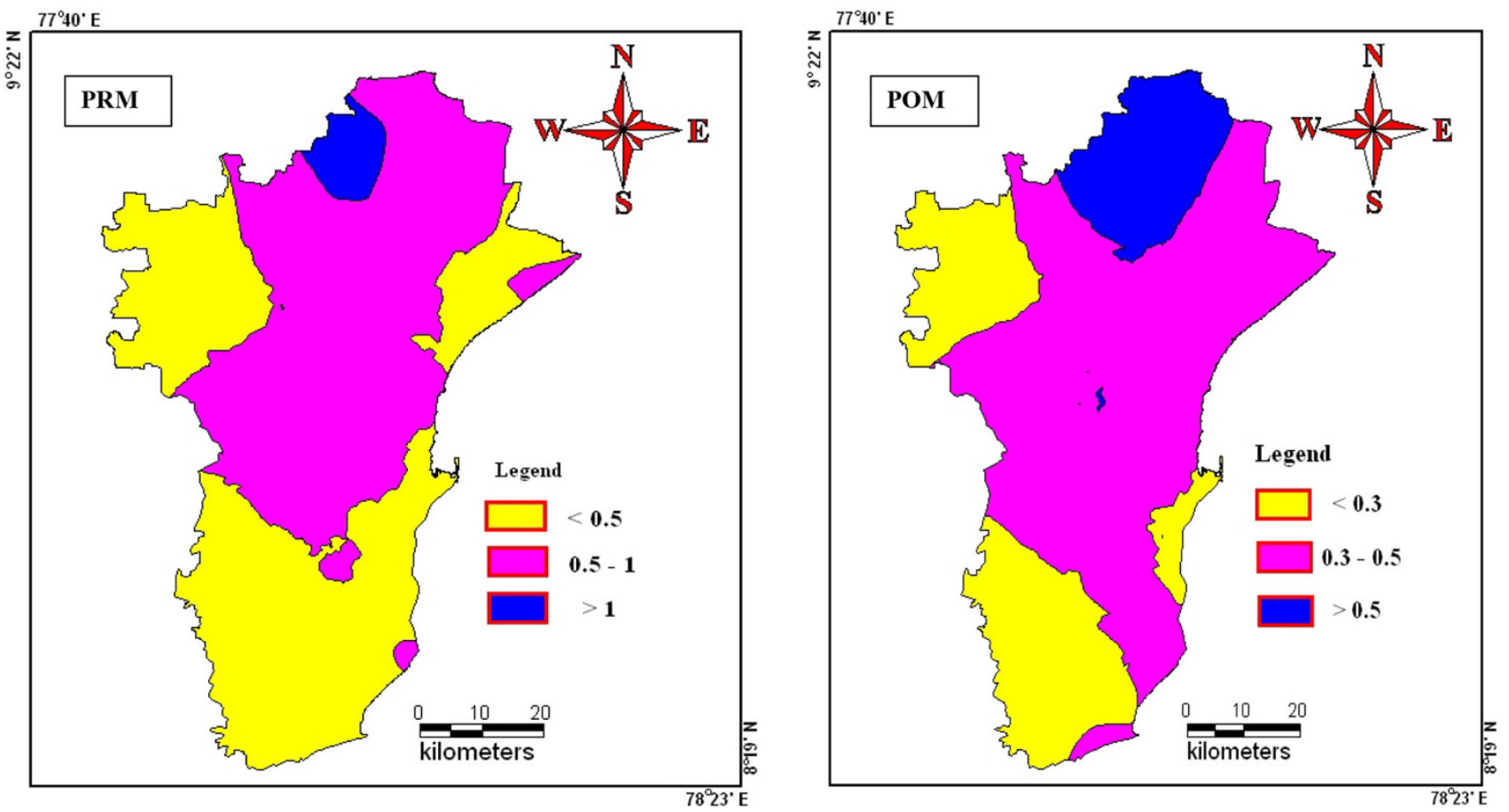

Fig. 3 Spatial and temporal distribution of $\mathrm{F}^{-}$concentrations $\left(\mathrm{mg} \mathrm{l}^{-1}\right)$ in the study area during PRM and POM

concentration of $\mathrm{F}^{-}$is observed in northwestern part of the study area as subsurface lithology has very low hydrologic conductivity and the clays present in the highly weathered rock mass might have resulted in the removal of $\mathrm{F}^{-}$by $\mathrm{OH}$ molecules through the process of ion exchange (Misra 2005; Singaraja et al. 2012; Manikandan et al. 2012). Moreover, the weathering of alkaline sedimentary rocks (especially Shales) may also result in removal of $\mathrm{F}^{-}$into soil from the groundwater (McNelly et al. 1979). The present study area also represents higher $\mathrm{F}^{-}$concentrations in the northern part of the region covered by hard rock (HBG) and few representations of charnockites.

Relationship between $\mathrm{F}^{-}$and $\mathrm{HCO}_{3}{ }^{-}$

Bicarbonate showed an increasing trend with $\mathrm{F}^{-}$concentration (Fig. 4) indicating incongruent dissolution of silicate minerals proceeded gradually with release of bicarbonate ion. It ranges from 12.2 to $536.8 \mathrm{mg} \mathrm{l}^{-1}$ and 50.4 to $683.2 \mathrm{mg} \mathrm{l}^{-1}$ during PRM and POM, respectively. Higher concentration of $\mathrm{F}^{-}$was also noted in PRM and less bicarbonate during POM; this may be due to leaching of secondary salts precipitated during summer season along the factures and cavities (Chidambaram et al. 2012). In general, it is noted that the bicarbonate and fluoride concentrations are lesser during POM and they get diluted during POM. Similar observations were obtained in the groundwaters of Dindigul District of Tamilnadu (Chidambaram et al. 2012) and also in Varaha River Basin,

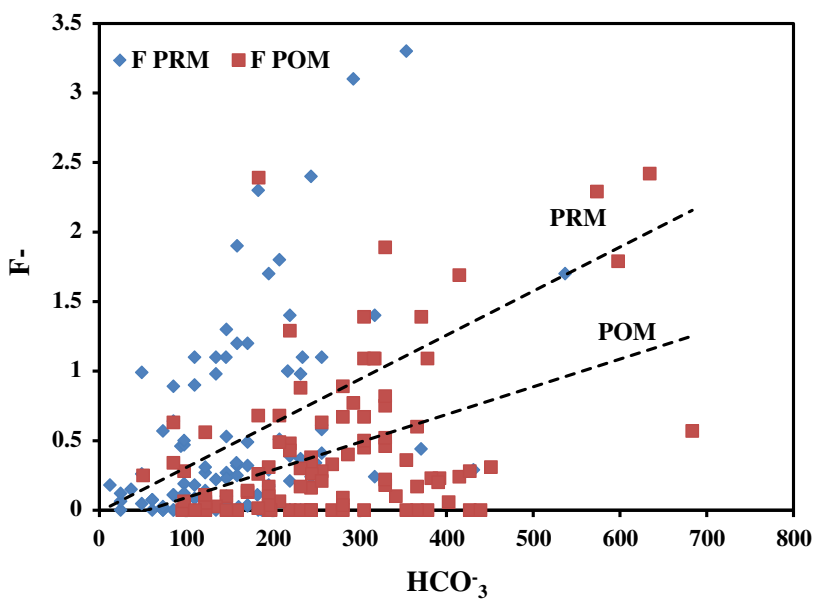

Fig. 4 Scatter plot between $\mathrm{HCO}_{3}{ }^{-}\left(\mathrm{mg} \mathrm{l}^{-1}\right)$ versus $\mathrm{F}^{-}\left(\mathrm{mg}^{-1}\right)$ in the Thoothukudi groundwater for both seasons

Visakhapatnam District, Andhra Pradesh, India (SubbaRao et al. 2012).

Saturation indices of fluoride minerals

The SI of $\mathrm{F}^{-}$minerals are seasonally highly variable (Fig. 5). In general, fluorine-bearing minerals such as fluorite and fluorapatite are responsible for a high concentration of fluoride under normal pressure and temperature conditions (Sunitha et al. 2012). Fluorite is undersaturated in both seasons and it shows an increasing 


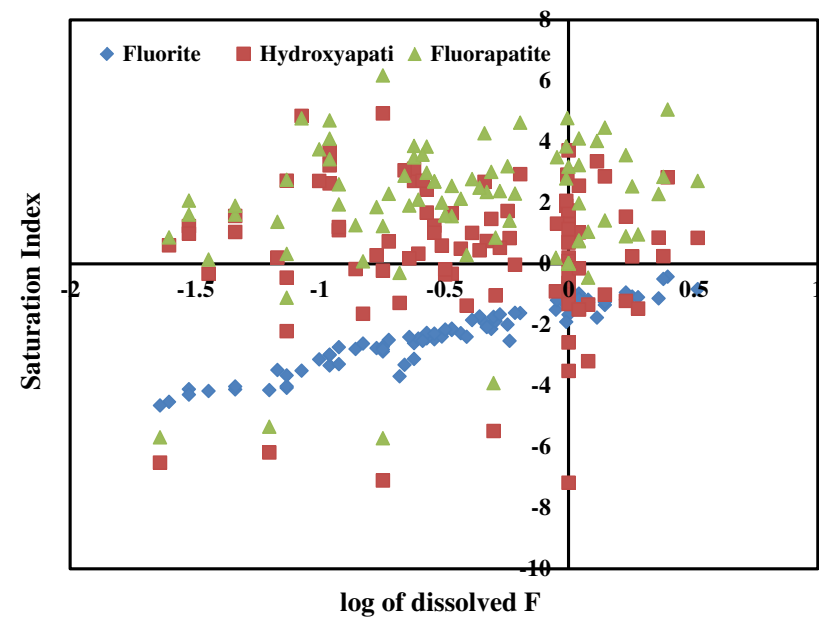

Fig. 5 Saturation indices of $\mathrm{F}^{-1}$ minerals as a function of $\log \mathrm{F}^{-1}$ concentrations during PRM

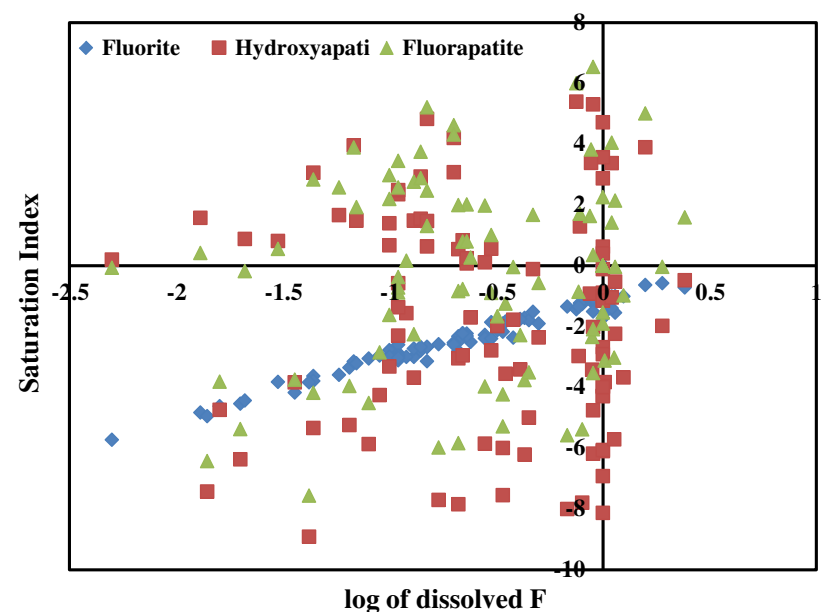

Fig. 6 Saturation indices of $\mathrm{F}^{-1}$ minerals as a function of $\log \mathrm{F}^{-1}$ concentrations during POM

trend with $\mathrm{F}^{-1}$. Fluorapatite and hydroxylapatite are saturated in PRM and they do not show a definite trend and few samples show undersaturation. During POM, dilution effect was clearly noted that almost all samples show undersaturation with the $\mathrm{F}^{-}$minerals except for few representation of SI of hydroxylapatite and fluorapatite (Fig. 6). It is noted that higher SI of $\mathrm{F}^{-}$minerals are higher during PRM and further it explains that the dilution effect influences the low SI of $\mathrm{F}^{-}$minerals in POM. In general, the order of SI is as follows: fluorapatite>hydroxylapatite $>$ fluorite. Fluoride is released into the groundwater and is instantaneously adsorbed by apatite and forms fluorapatite followed by the hydroxyl groups $\left(\mathrm{OH}^{-1}\right)$ in the hydroxyl apatite and at last they are preferred by $\mathrm{Ca}^{2+}$ to form fluorite as it requires two fluoride ions for a single calcium ion. This indicates that the temporal variability in fluoride minerals regulates the hydrogeochemical dynamics
Table 2 Summary of fluoride represented factors during PRM and POM periods of the study

\begin{tabular}{lcr}
\hline Seasons & PRM & POM \\
\hline Total no. of factors & \multicolumn{1}{c}{4} & \multicolumn{1}{c}{5} \\
Fluoride factor & 3 & 2 \\
$\mathrm{pH}$ & 0.17 & 0.26 \\
$\mathrm{Ca}^{2+}$ & 0.01 & -0.07 \\
$\mathrm{Mg}^{2+}$ & -0.01 & 0.05 \\
$\mathrm{Na}^{+}$ & 0.04 & -0.05 \\
$\mathrm{~K}^{+}$ & 0.09 & 0.03 \\
$\mathrm{~F}^{-}$ & 0.86 & 0.82 \\
$\mathrm{Cl}^{-}$ & -0.02 & -0.06 \\
$\mathrm{HCO}_{3}{ }^{-}$ & 0.80 & 0.82 \\
$\mathrm{PO}_{4}{ }^{-}$ & -0.01 & 0.15 \\
$\mathrm{NO}_{3}{ }^{-}$ & -0.04 & 0.01 \\
$\mathrm{SO}_{4}{ }^{2-}$ & 0.16 & 0.18 \\
$\mathrm{H}_{4} \mathrm{SiO}_{4}$ & -0.07 & 0.08 \\
$\%$ of variance & 12.42 & 22.05 \\
$\mathrm{TDV}^{-}$ & 75.00 & 69.30 \\
\hline
\end{tabular}

of fluoride in the Thoothukudi District groundwater system.

Factor analysis

The PCA analysis with varimax rotation is adapted to define the causative factors (called varifactors or VFs) which regulate the fluoride chemistry and distribution in the groundwater. The factor analysis was carried out for both seasons; four and five factors were extracted for PRM and POM seasons, respectively (Table 2). The representation of the total data variability (TDV) shows that higher representation of TDV was noted during PRM with $75 \%$ and POM (69.3\%). Liu et al. (2003) classified the factor loadings as 'weak', 'moderate' and 'strong', corresponding to the absolute loading values of $0.3-0.5 ; 0.5-0.75$ and $>0.75$, respectively.

In PRM, the representation of $\mathrm{F}^{-}$was noted as the third factor with strong positive loadings of $\mathrm{HCO}_{3}{ }^{-}$and low loadings of $\mathrm{pH}, \mathrm{Ca}^{2+}$ and $\mathrm{Mg}^{2+}$. Several authors have shown that in waters with high $\mathrm{F}^{-}$concentrations, the amount of $\mathrm{F}^{-}$is proportional to the $\mathrm{HCO}_{3}{ }^{-}$concentration (Handa 1975; Saxena and Ahmed 2001; Karro and Rosentau 2005; Singaraja et al. 2013d). It is an interesting point to note that high fluoride and very low $\mathrm{Ca}^{2+}$ and $\mathrm{Mg}^{2+}$ in water may be due to prior precipitation of $\mathrm{CaCO}_{3}$ from water and only limited incorporation of $\mathrm{F}^{-}$in the $\mathrm{CaCO}_{3}$ structure, so that there is always a net balance of $\mathrm{F}^{-}$ in solution (Kundu et al. 2001).The factor score was also estimated to find out the spatial variation of the factor representation and to identify the zone of its representation 

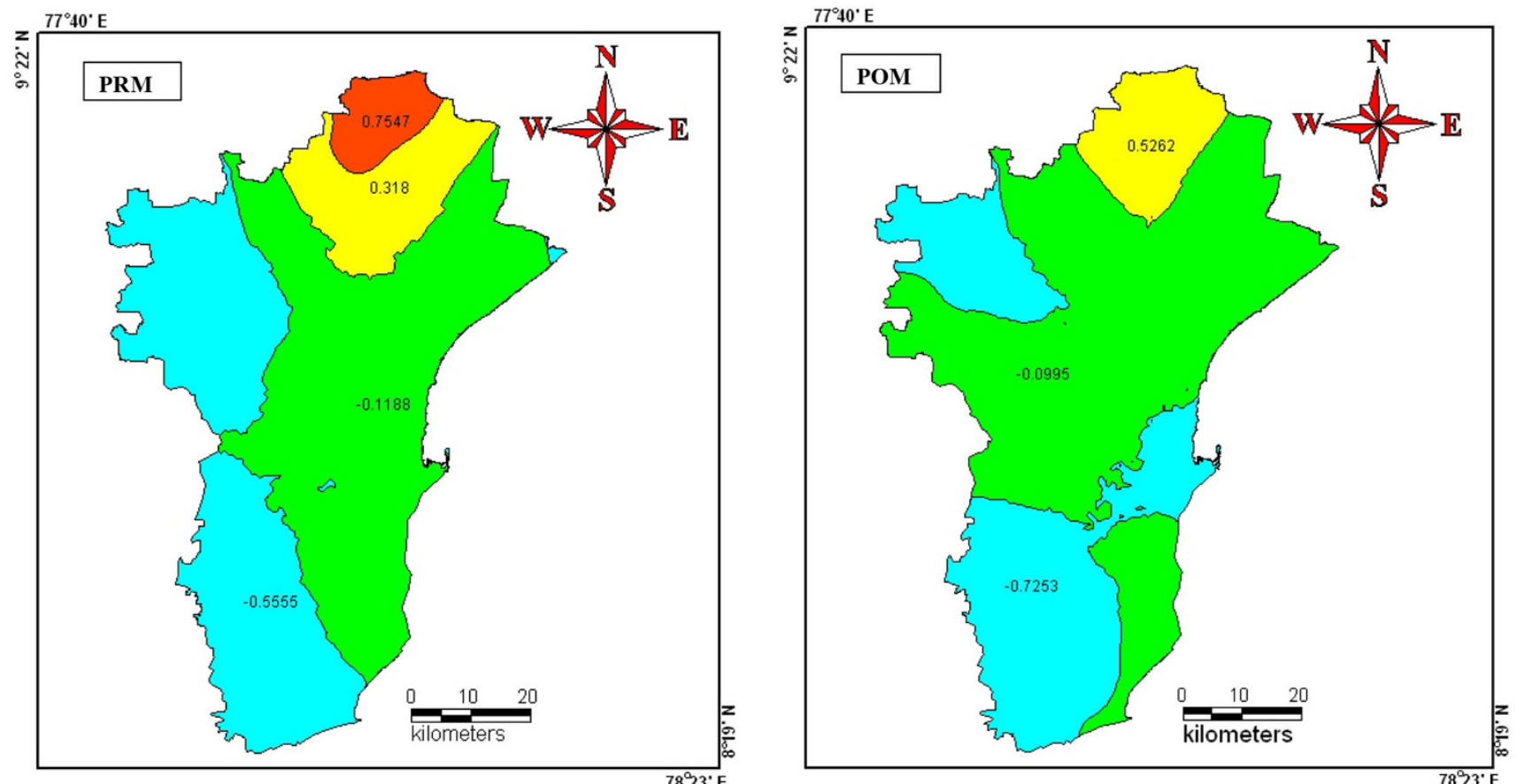

Fig. 7 Spatial distributions of $\mathrm{F}^{-1}$ factor score for the study area during PRM and POM

(Fig. 7). They are generally obtained by two approaches: weighted leastsquare method and the regression method. The regression method (Johnson and Wichern 1992) is used in the study to compute the factor scores. The positive zones indicate the dominance of that factor, hydrogeochemical regime (Chidambaram et al. 2007).The spatial representation of factor scores of each sample for this season shows that the positive representation of this factor is in the northern part of the study area. The northern part of the study area is chiefly composed of HBG and alluvial plain. There are high concentrations of fluoride in groundwater from hard rock terrain like HBG (Ramesham and Rajagopalan 1985; Chidambara et al. 2003).

In POM, Fluoride is represented as the second factor among the five factors of which the factor loadings were represented by $\mathrm{HCO}_{3}{ }^{-}$and $\mathrm{F}^{-}$and low loading of $\mathrm{pH}$, $\mathrm{Ca}^{2+}$ and $\mathrm{Mg}^{2+}$. High fluoride ground water is generally associated with high bicarbonate ions. This has also been observed by Chatterjee and Mohabey (1998) in their investigation at Madhya Pradesh in Central India. Low concentrations of $\mathrm{Ca}^{2+}$ and $\mathrm{Mg}^{2+}$ corresponding to high fluoride in the water have earlier been reported by Nanyaro et al. 1984; Teotia et al. (1981) who also observed an inverse relationship between $\mathrm{Ca}^{2+}$ and $\mathrm{Mg}^{2+}$, than the one suggested by Gaciri and Davies (1993) on the basis of solubility product of Calcite and Fluorite (Kundu et al. 2001). The spatial representation of factor scores shows the positive representation in the northern part of the study area (Fig. 7). $\mathrm{HCO}_{3}{ }^{-}$is positively correlated with $\mathrm{F}^{-}$during two seasons. The dissolved silica lacks representations in the factor loadings in PRM and POM seasons. Therefore, it is inferred that $\mathrm{F}^{-}$in groundwater is less influenced by the dissolution of silica. There was higher fluoride concentration in the northern part of the study area during both seasons. Fluoride ions from the minerals leach into the groundwater and contribute to high fluoride concentrations (Suttie 1969; Jubb et al. 1993; Schultheiss and Godley 1995). $\mathrm{pH}$ is an important factor that has influence on fluoride ion concentration in drinking water, but the relationship between $\mathrm{pH}$ and fluoride is weak, because the increase in alkalinity is due to the increase of carbonate and bicarbonate ions. These ions do not have direct influence on $\mathrm{pH}$ level like hydroxyl ion, so the increase of alkalinity does not increase the pH level linearly during PRM and POM (Wodeyar and Sreenivasan1996; SubbaRao et al. 1998; SubbaRao 2003). There was no significant relationship of chloride and sulphate level on fluoride ion concentration in drinking water as observed during PRM and POM and the results were comparable with a previous study (Rajmohan 2003).

\section{Conclusion}

In recent years, there has been an increase in $\mathrm{F}^{-}$concentration in Thoothukudi District, which causes adverse impact on human health. The study proves a significant variation in the chemical composition of groundwater and in $\mathrm{F}^{-}$concentration in both seasons. High concentration of fluoride is observed in PRM and low levels in POM, which 
is due to the effect of dilution after monsoon in the study area. The spatial distribution of $\mathrm{F}^{-}$in both the seasons reveals that highest fluoride concentrations are shown in the north and central part of the study area. This region is chiefly composed of the HBG, alluvial plain followed by charnockite, which aids as one of the main source for $\mathrm{F}^{-}$in the study area. It is also interesting to note that that alluvial plain groundwater has high fluoride levels due to alteration of mud and clay layers in the subsurface lithology which has very low hydrologic conductivity. The southern, western and the eastern parts of the study area do not suffer from $\mathrm{F}^{-}$contamination. Fluoride has a strong loading with $\mathrm{HCO}_{3}{ }^{-}$but very low loading of $\mathrm{pH}, \mathrm{Ca}^{2+}$ and $\mathrm{Mg}^{2+}$ during both seasons. It is interesting to note that increase of alkalinity is due to the increase of carbonate and bicarbonate ions, these ions not having direct influence on $\mathrm{pH}$ level, so the increase of alkalinity does not increase the $\mathrm{pH}$ and also show that very low $\mathrm{Ca}^{2+}$ and $\mathrm{Mg}^{2+}$ in water may be due to prior precipitation of $\mathrm{CaCO}_{3}$ and solubility product of calcite and fluorite in the study area.

Open Access This article is distributed under the terms of the Creative Commons Attribution License which permits any use, distribution, and reproduction in any medium, provided the original author(s) and the source are credited.

\section{References}

Acharya GD, Hathi MV, Patel AD, Parmar KC (2008) Chemical properties of groundwater in Bhiloda Taluka Region, North Gujarat, India. E-J Chem 5(4):792-796

Alagumuthu G, Rajan M (2010) Chemometric studies of water quality parameters of Sankarankovil block of Tirunelveli, Tamilnadu. J Environ Biol 31(5):581-586

Andezhath SK, Susheela AK, Ghosh G (1999) Fluorosis management in India: the impact due to networking between health and rural drinking water supply agencies. IAHS-AISH Publication 260:159-165

Bardsen A, Bgorraton K, Selving KA (1996) Variability in fluoride content of sub-surface water reservoir. Acta Odontol Scand 54:343-347

Central Ground Water Board (2009) South eastern coastal region, District groundwater brochure, Thoothukudi district, Tamil nadu

Chadha DK, Tamta SR (1999) Occurrence and origin of groundwater fluoride in phreatic zone of Unnao district, Uttar Pradesh. J Appl Geochem 1:21-26

Chatterjee MK, Mohabey NK (1998) Potential fluorosis problems around Chandidongri, Madhya Pradesh, India. Environ Geochem Health 20:1-4

Chidambara S, Ramanathan AL, Srinivasamoorthy K (2003) Lithological influences on the groundwater chemistry-Periyar district a case study. In: Conference on coastal and freshwater issue, p173. 12, pp 625-636

Chidambaram S, Bala Krishna Prasad M, Manivannan R, Karmegam U, Singaraja C, Anandhan P, Prasanna MV, Manikandan S (2012) Environmental hydrogeochemistry and genesis of fluoride in groundwaters of Dindigul district, Tamilnadu (India). Environ Earth Sci. doi:10.1007/s12665-012-1741-9

Chidambaram S, Ramanathan AL, Srinivasamoorthy K, Anandhan P (2003) WATCLAST - a computer program for hydrogeochemical studies. Recent trends in Hydrogeochemistry (case studies from surface and subsurface waters of selected countries). Capital Publishing Company, New Delhi pp 203-207

Chidambaram S, Ramanathan AL, Prasanna MV, Anandhan P, Srinivasamoorthy K, Vasudeven S (2007) Identification of Hrogeochemically Active Regimes in Groundwaters of Erode District,Tamilnadu A Statistical Approach. Asian J water, Environ pollut 5(3):93-102

Clark DC (1993) Appropriate uses of fluorides for children: guidelines from the Canadian workshop on the evaluation of current recommendations concerning fluorides. CMAJ 149:1787-1793

Deepu TR, Shaji E (2011) Fluoride contamination in groundwater resources of Chittur block, Palghat district, Kerala, India-a health risk. Disaster, risk and vulnerability conference. School of Environmental Sciences, Mahatma Gandhi University, India in association with the Applied Geoinformatics for Society and Environment, Germany March 12-14

Gaciri SJ, Davies TC (1993) The occurrence and geochemistry of fluoride in some natural waters of Kenya. J Hydrol 143:395-412

Gizaw B (1996) The origin of high bicarbonate and fluoride concentration in waters of the main Ethiopian rift valley, east African rift system. J Afr Earth Sci 22:391-402

Gupta SK, Deshpande RD, Agarwal M, Raval BR (2005) Origin of high fluoride in groundwater in the North Gujarat-Cambay region, India. Hydrogeol J 13:596-605

Hammarstrom JM, Seal RR II, Meier AL, Kornfeld JM (2005) Secondary sulfate minerals associated with acid drainage in the eastern US: recycling of metals and acidity in surficial environments. Geochemistry of sulfate minerals: a tribute to Robert $\mathrm{O}$. Rye. Paper 2. http://digitalcommons.unl.edu/usgsrye/2

Handa BK (1975) Geochemistry and genesis of fluoride containing groundwater in India. Ground Water 13:275-281

Hussain J (2001) Studies on the impact of industrial and domestic waste on groundwater quality, Ph.D. Thesis, MDS University Ajmer Rajasthan, India

Hussain J, Sharma KC, Hussain I (2004) Fluoride in drinking water and its ill affect on human health: a review. J Tissue Res 4(2):263-273

Hussain J, Hussain I, Sharma KC (2010) Fluoride and health hazards: community perception in a fluorotic area of Central Rajasthan (India): an arid environment. Environ Monit Assess 162:1-14

Jacks G, Bhattacharya P, Choudary V, Singh KP (2005) Controls on the genesis of some high fluoride ground waters in India. Appl Geochem 20:221-228

Johnson RA, Wichern DW (1992) Applied multivariate statistical analysis, 3rd edn. Prentice Hall, New Jersey

Jolly SS, Prasad S, Sharma R, Chander R (1973) Endamic fluorosis in Punjab. I. Skeletal aspects. Fluoride 6:4-18

Jones CM, Taylor GO, Whittle JG, Evans D, Trotter DP (1997) Water fluoridation, tooth decay in 5 year olds, and social deprivation measured by the Jarman score: analysis of data from British dental surveys. BMJ 315:514-517

Jubb TF, Annand TE, Main DC, Murphy GM (1993) Phosphorus supplements and fluorosis in Cattle-a northern Australian experience. Aust Vet J 70:379-383

Karro E, Rosentau A (2005) Fluoride levels in the silurian-ordovician aquifer system of western Estonia, research report. Fluoride 38(4):307-311

Karthikeyan G, Shanmugasundarraj A (2000) Mapping of fluorotic areas using isopleths technique and in situ fluoride dependence on water quality. Fluoride 33(3):121-127

Kim K, Jeong YG (2005) Factors influencing natural occurrence of fluoride-rich ground waters: a case study in the southeastern part of the Korean Peninsula. Chemosphere 58:1399-1408

Kim KH, Yun ST, Chae GT, Kim SY, Kwon JS, Koh YK (2006) Hydrogeochemical evolution related to high fluoride 
concentrations in deep bedrock groundwaters, Korea. Economic Environ Geo 39(1):12-17

Kundu N, Panigrahi MK, Tripathy S, Munshi S, Powell MA, Hart BR (2001) Geochemical appraisal of fluoride contamination of groundwater in the Nayagarh district of Orissa, India. Environ Geol 41:451-460

Li Z, Tainosho Y, Shiraishi K, Owada M (2003) Chemical characteristics of fluorine-bearing biotite of early Paleozoic plutonic rocks from the SorRondane Mountains, East Antarctica. Geochem J 37:145-161

Liu WX, Li XD, Shen ZG, Wang DC, Wai OWH, Li YS (2003) Multivariate statistical study of heavy metal enrichment in sediments of the Pearl river estuary. Environ Pollut 121:377-388

Manikandan S, Chidambaram S, Ramanathan AL, Prasanna MV, Karmegam U, Singaraja C, Paramaguru P, Jainab I (2012) A study on the high fluoride concentration in the magnesium-rich waters of hard rock aquiferin Krishnagiri district, Tamilnadu, India. Arab J Geosci doi:10.1007/s12517-012-0752-x

McNelly RN, Neimenia IP, Dwyer L (1979) A guide to water quality parameters: inland water directorate, Canada, pp 1-65

Misra AK (2005) Integrated water resource management and planning for its sustainable development using remote sensing and GIS techniques in the dark areas of Agra and Mathura district, Uttar Pradesh. Dissertation, University of Lucknow

Misra AK, Mishra A, Premraj R (2006) Escalation of groundwater fluoride in the Ganga alluvial plain of India, research report. Fluoride 39(1):35-38

Nanyaro JT, Aswathanarayana U, Mungore JS, Lahermo PW (1984) A geochemical model for the abnormal fluoride concentrations in waters in parts of northern Tanzania. J Afr Earth Sci 2:129-140

Nordstrom DK, Ball JW, Donahoe RJ, Whittemore D (1989) Groundwater chemistry and water-rock interactions at Stripa. Geochim Cosmochim Acta 53:1727-1740

Oruc N (2003) Problems of high fluoride waters in Turkey (hydrogeology and health aspects). The short course on medical geology-health and environment. Canberra, Australia

Pickering WF (1985) The mobility of soluble fluoride in soils. Environ Pollut 9:281-308

Pillai KS, Stanley VA (2002) Implications of fluoride-an endless uncertainty. J Environ Biol 23:81-97

Rajmohan N (2003) Major correlation in ground water of Kancheepuram region, South India. Indian J Environ Health 45(1):1-5

Ramachandran M, Sabarathinam C, Ulaganthan K, Paluchamy A, Sivaji M, Hameed S (2010) Mapping of fluoride ions in groundwater of Dindigul district, Tamilnadu, India—using GIS technique. Arab J Geosci 5:433-439. doi:10.1007/s12517-0100216-0

Ramesham V, Rajagopalan K (1985) Fluoride ingestion into the natural waters of hardrock areas, Peninsular India. J Geol Soc India 26:125-132

Rao N, Devadas DJ (2003) Fluoride incidence in groundwater in an area of Peninsular India. Environ Geol 45:243-251

Reddy DV, Nagabhushanam P, Sukhija BS, Reddy AGS, Smedley PL (2010) Fluoride dynamics in the granitic aquifer of the Wailapally watershed, Nalgonda District, India. Chem Geol 269:278-289

Ripa LW (1993) A half-century of community water fluoridation in the United States: review and commentary. J Public Health Dent 53:17-44

Saxena VK, Ahmed S (2001) Dissolution of fluoride in groundwater: a water-rock interaction study. Environ Geol 40(8):1084-1087

Schultheiss WA, Godley GA (1995) Chronic fluorosis in cattle due to the ingestion of a commercial lick. J S Afr Vet Assoc 66(2):83-84
SelvinPitchaikani J, Ananthan G, Sudhakar M (2010) Studies on the effect of coolant water effluent of Tuticorin thermal power station on hydro biological characteristics of Tuticorin coastal waters, south east coast of India. Curr Res J Biol Sci 2(2):118-123

Shaji E, BinduViju J, Thambi DS (2007) High fluoride in groundwater of Palghat district, Kerala. Curr Sci 92:240-245

Shortt WE (1937) Endemic fluorosis in Nellore District, South India. Indian Med Gazette 72:396

Siddiqui AH (1955) Fluorosis in Nalgonda district, HyderabadDeccan. Brit Med J 2:1408-1413

Siddiqui AH (1968) Fluorosis in Nalgonda district Hyderabad, India. Fluoride 1(2):76-85

Singaraja C, Chidambaram S, Anandhan P, Prasann MV, Thivya C, Thilagavathi R (2012) A study on the status of fluoride ion in groundwater of coastal hard rock aquifers of south India. Arabian Journal of Geosciences 6: 4167 - 4177. doi:10.1007/ s12517-012-0675-6

Singaraja C, Chidambaram S, Anandhan P, Prasanna MV, Thivya C, Thilagavathi R, Sarathidasan J (2013a) Hydrochemistry of groundwater in a coastal region and its repercussion on quality, a case study-Thoothukudi district, Tamilnadu, India. Arab J Geosci. doi:10.1007/s12517-012-0794-0

Singaraja C, Chidambaram S, Prasanna MV, Thivya C, Thilagavathi R (2013b) Statistical analysis of the hydrogeochemical evolution of groundwater in hard rock coastal aquifers of Thoothukudi district in Tamilnadu, India. Environ Earth Sci. doi:10.1007/ s12665-013-2453-5

Singaraja C, Chidambaram S, Prasanna MV, Thivya C, Thilagavathi R (2013c) Appraisal of water quality pollution Indices for heavy metal contamination monitoring: A case study from Thoothukudi Districts, Tamilnadu, India. Inventi Rapid: Water Environ 4:1-5

Singaraja C, Chidambaram S, Anandhan P, Prasann MV, Thivya C, Thilagavathi R, Sarathidasan J (2013d) Determination of the utility of groundwater with respect to the geochemical parameters: a case study from Tuticorin District of Tamil Nadu (India). Environ Dev Sustain. doi:10.1007/s10668-013-9502-9

Singh R, Maheshwari RC (2001) Defluoridation of drinking water-a review. Indian J Environ Prot 21(11):983-991

Srinivasamoorthy K (2005) Hydrogeochemistry of Groundwater in Salem district, Tamilnadu, India. Published PhD thesis, Annamalai University

Srinivasamoorthy K, Chidambaram M, Prasanna MV, Vasanthavigar M, John Peter A, Anandhan P (2008) Identification of major sources controlling groundwater chemistry from a hard rock terrain-a case study from Mettur taluk, Salem district, Tamilnadu, India. J Earth Syst Sci 117(1):49-58

SubbaRao N (2003) Groundwater quality: focus on fluoride concentration in rural parts of Guntur districts, Andhra Pradesh, India. Hydrol Sci J 48(5):835-847

SubbaRao N (2009) Fluoride in groundwater, Varaha River Basin, Visakhapatnam District, Andhra Pradesh, India. Environ Monit Assess 152:47-60

SubbaRao N, Prakasa Rao J, Nagamalleswara Rao B, Nirranjan Babu P, Madhusudhana Reddy P, John Devadas D (1998) A preliminary report on fluoride content in groundwaters of Guntur area, Andhra Pradesh, India. Current Sci 75:887-888

SubbaRao N, Surya Rao P, Venktram Reddy G, Nagamani M, Vidyasagar G, Satyanarayana NLVV (2012) Chemical characteristics of groundwater and assessment of groundwater quality in Varaha River Basin, Visakhapatnam District, Andhra Pradesh, India. Environ Monit Assess 184:5189-5214. doi:10.1007/ s10661-011-2333-y

Sunitha V, Reddy BR, Reddy MR (2012) Groundwater quality evaluation with special reference to fluoride and nitrate pollution

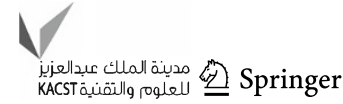


in Uravakonda, Anantapur District, Andhra Pradesh-a case study. Int J Res Chem Environ 2(1):88-96

Susheela AK (1999) Fluorosis management programme in India. Curr Sci 77(10):1250-1256

Suttie JW (1969) Fluoride content of commercial dairy concentrates and alfalfa forage. J Agric Food Chem 17:1350-1352

Tahaikt M, AitHaddou A, El Habbani R, Amor Z, Elhannouni F, Taky M, Kharif M, Boughriba A, Hafsi M, Elmidaoui A (2008) Comparison of the performances of three commercial membranes in fluoride removal by nanofiltration, continuous operations. Desalination 225:209-219

TaheriTizro A, Voudouris KS (2008) Groundwater quality in the semi-arid region of the Chahardouly basin, West Iran. Hydrol Process 22:3066-3078

Teotia SDS, Teotia M, Singh RK (1981) Hydrogeochemical aspects of endemic skeletal fluorosis in India-an epidemiological study. Fluoride 14:69-74

USPHS (1962) Drinking water standard, Washington: USPHS, Publication 956, USGPO

Veeraputhiran V, Alagumuthu G (2010) A report on fluoride distribution in drinking Water. Int J Environ Sci 1:4
Vollmer C (1993) Unter suchungenüber den Fluoridgehalt des Trinkwassersausprivaten was server sorgungs anlagen der Region Rietberg 3 (Mastholte). Dissertation, Münster

Wang Y, Reardon EJ (2001) Activation and regeneration of a soil sorbent for defluoridation of drinking water. Appl Geochem 6:531-539

Wenzel WW, Blum WEH (1992) Fluoride speciation and mobility in fluoride contaminated soil and minerals. Soil Sci 153:357-364

WHO (1984) Guidelines for drinking water quality, vol. 3. Drinking water quality control in small community supplies. Geneva

WHO (1997) Guideline for drinking water quality health criteria and other supporting information, 2nd edn, vol 2. World Health Organization, Geneva

WHO (2008) International standards for drinking water, 3rd edn, Geneva

Wodeyar BK, Sreenivasan G (1996) Occurrence of fluoride in the groundwaters and its impact in Peddavankahalla Basin, Bellary District, Karnataka, India—a preliminary study. Curr Sci 70:71-74 